\title{
Latin and Hebrew Analogues to the Old Norse Leek Riddle
}

\begin{abstract}
Alaric Hall*
It has been thought that of the forty or so surviving Old Norse riddles, only two have close parallels in the wider international riddle tradition. This note shows, however, that the riddle on the leek in the probably thirteenth-century Heiðreks saga has a close parallel in one of the late antique or early medieval Bern Riddles, on garlic. Moreover, the larger conceptual structure of the leek riddle, which positions the leek as an inverted person situated between the earth and the sun, is paralleled by one of the riddles of the tenth-century Hebrew poet Dunash ben Labrat ha-Levi, which figures the sun and its light as a tree with its roots in the sky and its branches in the ground. The riddles of Heiðreks saga are more integrated into wider riddle culture than has been realised, and comparison of Dunash's work with the Old Norse and Latin material helps to settle debate about the solution to Dunash's riddle.
\end{abstract}

Keywords: riddles, Heiðreks saga, Bern Riddles, Dunash ben Labraț ha-Levi, allium

This note brings together three medieval verse riddles, in Old Norse, Latin, and Hebrew, to reveal hitherto unappreciated similarities between the riddle literature of these languages. Our Old Norse riddles have been thought to show few overlaps with wider riddle traditions, but I show that the riddle on the leek in Heidreks saga uses the same conceit as one of the riddles on garlic in the Latin Bern Riddles. In both riddles, the allium is figured as a person with their head in the earth and their feet in the air; and both harness this image to religious or mythic ideas about death. Meanwhile, one of the riddles of the tenth-century Hebrew poet Dunash ben Labrat ha-Levi uses similar imagery. This indicates that the conceptual structure seen in the Latin and Norse had a wider circulation, and the comparisons between the three riddles help us to resolve debate about the solution to Dunash's composition, supporting the idea that his riddle is on the sun.

All but four of our surviving Old Norse riddles are preserved in the various manuscripts of the probably thirteenth-century Heiðreks saga, which features a riddle contest in which Óinn, chief of the traditional Old Norse gods, disguised as a man called Gestumblindi, poses riddles in verse to the saga's eponymous anti-hero, King Heiðrekr. The riddles total thirty-seven in Burrows's recent critical edition. ${ }^{1}$ In his edition and translation of the saga, Christopher Tolkien asserted that

* Correspondence details: Alaric Hall, University of Leeds, a.t.p.hall@leeds.ac.uk

1 Hervarar saga ok Heiðreks, ed. Burrows. 
Gestumblindi's riddles are unique, in more senses than one. They are unique in that there are no others in ancient Norse; and even more surprisingly, there is no record in the poetry or in the sagas of a riddle ever having been asked. They are unique also in that there are no parallels to them in the riddle-literature of any other country, apart from the ancient 'Cow-riddler (verse 70), which is known all over Europe, and the very curious riddle of the sSow with the Unborn Litters (verse 69). ${ }^{2}$

Tolkien's implication that there are no other Old Norse riddles was wrong: three are known outside Heiðreks saga, with their earliest manuscript being AM $6254^{\circ}$, from c. 1300 - no younger than Hauksbók, the first witness to Heiðreks saga. ${ }^{3}$ Philip Lavender has recently called attention, moreover, to the fact that a riddle is posed in another Old Icelandic text, Ejalar-Jóns saga. ${ }^{4}$ But although Hannah Burrows and others have recently done valuable work demonstrating the degree to which the Heiðreks saga riddles are embedded in Old Norse poetic and mythological tradition, ${ }^{5}$ Tolkien's claim that all but two of the riddles are unparalleled has stood unchallenged. ${ }^{6}$

Shamira A. Meghani and I have recently argued that, contrary to Tolkien's claim, one of the Heidreks saga riddles, on angelica, has parallels in the Latin, Greek, Hebrew, and Arabic riddling of the early Middle Ages. ${ }^{7}$ The present note shows that the other riddle about a plant in the collection also has a close medieval Latin parallel and more distant Hebrew ones: ${ }^{8}$

Hvat er pat undra, er ek úti sá

fyrir Dellings durum?

Höfði sínu vísar á helvega, en fótum til sólar snýr.

Heiðrekr konungr, hyggðu at gátu.

Góð er gáta pín, Gestumblindi, getit er pessar; pat er laukr; hǫfuð hans er fast í jǫrðu, en hann kvíslar, er hann vex upp.

What is that marvel which I saw outside, in front of the doors of Dellingr?

With its head it indicates the roads to Hel, but with its feet it turns to the sun.

Consider the riddle, King Heiðrekr.

Your riddle is good, Gestumblindi; it has been guessed. That is a leek/allium: its head is firmly in the earth, but it forks as it grows upwards.

2 Saga of King Heidrek the Wise, ed. and trans. Tolkien, xix.

3 Hall, Changing style and changing meaning, 9; Gátur, ed. Burrows; Stefán Karlsson, Aldur Hauksbókar.

4 Lavender, bjalar-Jóns saga, 88.

5 Burrows, Enigma variations; Wit and wisdom; Hervarar saga ok Heiðreks, ed. Burrows; Vijūna, On the Old Icelandic riddle collection; to which we can belatedly add the commentary by Björn Jónsson á Skarðsá (1574-1655), Útlegging Bjarna Jónssonar uppá pessar gátur Gests ins blinda, ed. Lavender.

6 Cf. Hervarar saga ok Heiðreks, ed. Burrows, 407, and 422-423 on the sow with the unborn litter.

7 Hervarar saga ok Heiðreks, ed. Burrows, 429 [verse 65]; Hall and Meghani, »I am a virgin woman«.

8 For the verse, Hervarar saga ok Heiðreks, ed. Burrows, 417 [verse 55]; for the prose Saga of King Heidrek the Wise, ed. Tolkien, 35 [verse 50]; translations are my own unless otherwise stated. 
The best translation of laukr is somewhat uncertain: its English cognate is leek and this reflects the prototypical meaning of laukr, but the semantic range of laukr extended across the allium family. ${ }^{9}$ Either way, it is unsurprising that one of our two Old Norse riddles on plants should be about an allium: while domesticated alliums seem to have been introduced into the Germanic-speaking world from the Mediterranean in the Iron Age, they were so well embedded into early medieval Germanic (and Insular Celtic) culture as to constitute the prototypical vegetable. ${ }^{10}$ Indeed, of the ninety-five or so Old English riddles of the Exeter Book, only two are likely to have plants as their solutions, and both are on alliums (probably the onion). ${ }^{11}$

I offer two analogues to the laukr riddle. The first and closer is from the Latin Bern Riddles, probably composed in the Mediterranean region (and perhaps specifically northern Italy) around the seventh century. ${ }^{12}$ In the critical edition of Glorie, it runs: ${ }^{13}$

De alio.

Multiplici ueste natus de matre productor

Nec habere corpus possum, si uestem amitto.

Meos, unde nasco, in uentre fero parentes;

Viuo nam sepultus, uitam et inde resumo.

Superis eductus nec umquam crescere possum,

Dum natura caput facit succedere plantis.

On garlic.

I am brought forth, born from my mother, with many-layered clothing;

I cannot have a body if I lose my clothing.

I carry my parents, from whom I am born, in my womb/stomach;

I live though interred, and from that place I resume my life.

I can never grow up, nurtured, to a great height,

since Nature makes my head go beneath my shoots/the soles of my feet.

It is the second half of this poem which parallels the Old Norse leek riddle. In both, the allium is metaphorically an inverted person, the bulb their head, its forked shoots their legs, and both riddles take the opportunity to counterpose human death with vegetal life. The metaphor may in both cases build on the everyday use of words for "head " to denote the bulb of an allium: according to the Dictionary of Old Norse Prose, Heiðrekr's response to the laukr riddle is the only Old Norse evidence for this usage, but it is attested in Old English, suggesting that the usage might have been more widespread in the Germanic languages than our medieval sources reveal, and is also attested, albeit perhaps not extensively, in Latin. ${ }^{14}$ According to Heiðreks saga, the laukr "hǫfði sínu / vísar á helvega | en fótum til sólar snýr" ("with its head indicates the roads to Hel, but with its feet turns to the sun«). In Burrows's estimation,

9 Markey, >Leeks` in their early folk contexts.

10 Markey, >Leeks in their early folk contexts.

11 The Exeter Book, ed. Krapp and Dobbie, 193, 230 (nos. 25 and 65).

12 Klein, Latin Bern Riddles; Mogford, Moon and stars, 231.

13 Aenigmata in Dei nomine Tullii, ed. Glorie, 598 (no. 51).

14 Dictionary of Old Norse Prose, s.v. laukr; Oxford English Dictionary Online, s.v. head, n. 1 §15a; Lewis and Short, Latin Dictionary, s.v. căpŭt § I.2.a. 
the riddle sets this vegetable into a cosmic world-view, consonant with the pre-Christian setting of Heidreks saga, as "a bridge between the underworld and the sun «. ${ }^{15}$ With a firmer optimism, consonant with a cultural context more extensively infused with Christian ideas, the garlic bulb of the Bern Riddles says "uiuo nam sepultus, uitam et inde resumo" (»I live though interred, and from that place I resume my life«). The resonances between the Norse leek riddle and the Bern garlic riddle, then, are strong.

It is not impossible that the Bern garlic riddle influenced the Norse laukr riddle directly. We have no direct evidence that the Bern Riddles were known in medieval Iceland. But, as Tolkien noted, the riddle on the Sow with the Unborn Litter is best paralleled by Enigma 84 of the early medieval West-Saxon poet Aldhelm, who wrote in Latin and whose work probably drew on the Bern Riddles. ${ }^{16}$ If Aldhelm influenced Heiðreks saga, directly or indirectly, it is not unlikely that the Bern Riddles could have too. Moreover, part of Heiðreks saga's riddle about a dead snake on an ice-floe also appears, in a section of the Old Icelandic Third Grammatical Treatise translated from Donatus's Ars maior, as a Norse equivalent to a riddle about ice quoted by Donatus. ${ }^{17}$ This does not suggest that the Norse dead snake riddle is a translation of the Latin - quite the opposite - but does indicate that vernacular verse riddles were circulating in a not entirely separate sphere from the world of Latin learning in Iceland.

On the other hand, it is self-evidently plausible that these Norse and Latin allium riddles might owe their similarity to the oral circulation of riddle tropes. This being so, it is worth noting the conceptual similarities in these two riddles with the eighth of ten two-line riddles attributed to the seminal medieval Hebrew poet (and husband to probably the only known female Hebrew-language poet of the Middle Ages), Dunash ben Labrat ha-Levi (920×925-after 985), who undertook his most noted literary endeavours in al-Andalus, but who seems to have been born in the Maghreb and also to have studied in Iraq.$^{18}$ The earliest manuscript of the riddle is the Cairo Geniza fragment Philadelphia, University of Pennsylvania, Center for Advanced Judaic Studies Library, Cairo Genizah Collection, Halper 317, f. 2v (lines 29-30), from between the tenth and the twelfth century; its riddles were edited by Nehemya Aluny in $1945 .{ }^{19}$







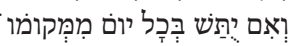

15 Burrows, Wit and wisdom, 123.

16 Saga of King Heidrek the Wise, ed. Tolkien, 90; Hervarar saga ok Heiðreks, ed. Burrows, 422-423; Klein, Latin Bern Riddles.

17 Saga of King Heidrek the Wise, ed. Tolkien, 37 [verse 54]; Hervarar saga ok Heidreks, ed. Burrows, 438-439 [verse 72].

18 Delgado, Dunash ben Labrat ha-Levi.

19 Dunash ben Labraț ha-Levi, hidot, ed. Aluny, 145. Halper 317 is available in an open-access facsimile: openn. library.upenn.edu/Data/0oo2/html/h317.html. 
Apparently without knowledge of Aluny's edition, Dan Pagis, working from the earlier edition of Hayim Nahman Bialik and Yehoshua Hana Rawnitzki, or one like it, translated the riddle into English as "What tree is it whose branches are in the earth, its roots the Lord created in the heavens / Who bears pleasant fruit in its season, though be it uprooted at any moment? «. ${ }^{20}$ A manuscript from St Petersburg, for which Aluny gave no shelf mark or other information and which I have not yet identified (but which presumably lies in the collections of Abraham Firkovich held in the National Library of Russia), gives the riddle's solution in Judaeo-Arabic as (fi al-ilm, ״on knowledge"), and several commentators of the nineteenth and earlier twentieth century accepted this interpretation. Others have ventured "a wise man" or simply "a man «. ${ }^{21}$ Bialik and Rawnitzki, however, suggested the solution "sun". Their solution fits the text of Halper 317 better than it does the later manuscripts on איום בכָלל (b-khol yom, "each day") where their edition gives (b-khol et, rendered by Pagis above as "at any moment«). The sun, located in the heavens, is the point of origin (and therefore the roots) of the sunbeams which extend, like tree-branches, to the earth; the sun's heat and light are its fruit, and the sun disappears each day. It is hard to make "wisdom " fit the riddle so neatly. Accordingly, Rodríguez, translating the Halper 317 text, accepted the solution "sun" without comment in his translation of Dunash's diwan, and Pagis too supported this solution. He agreed with Bialik and Rawnitzki that this interpretation is supported by the following description of the sun in an epigrammatic verse-capping contest - a poem that is not therefore a riddle but also not unlike a riddle - portrayed in chapter 32 of the Tahkemoni by Yehudah ben Shelomo al-Harizi (d. 1225). ${ }^{22}$ The poem runs: ${ }^{23}$

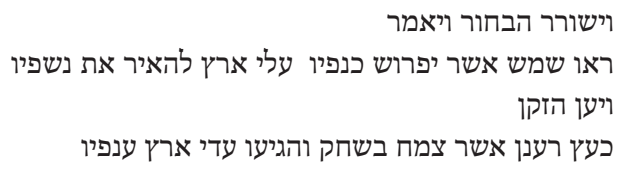

Then the Youth sang and said:

See the sun which spreads its wings

Upon the earth to illumine its twilight.

And the Old Man answered and said:

Like a leafy tree that sprouts in the skies

And its branches reach to the earth.

Al-Harizi's poem certainly attests to the viability of using an inverted tree as a metaphor for the sun's light in medieval Hebrew verse. Given the paucity of research on Dunash's riddles, it seems reasonable to accept Rodríguez and Pagis's apparently independent views to constitute a consensus among modern scholars that Dunash's eighth riddle is indeed on the sun.

20 Ibn Gabirol, shire Shelomoh ben Yehudah ibn Gabirol, ed. Bialik and Rawnitzki, V 35.

21 Dunash ben Labrat ha-Levi, hidot, ed. Aluny, 145-46; Pagis, Toward a theory, 105-106 [n. 36].

22 Ibn Gabirol, shire Shelomoh ben Yehudah ibn Gabirol, ed. Bialik and Rawnitzki, V 41 (commentary); Dunash ben Labrat ha-Levi, diwan, trans. Rodríguez, 228.

23 Al-Harizi, Tahkemoni, 131; trans. Reichert, II 184. 
In the Old Norse riddle, the plant is the solution and the sun is part of the metaphor which positions the plant as an inverted being that links the sun to the earth. In Dunash's riddle, it is the sun that is the solution, and the inverted plant constitutes the metaphor. Like the other riddles, Dunash's takes the opportunity of this cosmic image to give a mythological (and specifically theological) angle to the riddle, in this case explicitly positioning the sun and its light as the creation of the Abrahamic God in the heavens.

There is no likely prospect of a direct, written connection between Dunash's sun riddle and the Old Norse leek riddle; mutual influence from the Bern riddle, which could have been read in both medieval Iceland and Iberia, is conceivable, but Dunash's riddle has much less in common with the Bern riddle than with the Old Norse one. There were perhaps more opportunities for spoken conversations to arise between medieval Scandinavians and Iberians than literary contacts, and so potentially for the oral exchange of literary ideas. ${ }^{24}$ But it is equally easy to imagine the similarities between the texts presented here as arising either from a potentially older and certainly more diffuse Eurasian riddle culture, or from independent innovation. Whatever the case, it is clear that in the instance of the leek riddle, the riddles of Heiðreks saga are not as different from Eurasian riddling as commentators have thought, if only because of a clear Latin analogue. Meanwhile, the leek riddle helps to consolidate recent arguments that Dunash's eighth riddle is about the sun by showing the viability of a similar set of images in a roughly contemporary riddle elsewhere.

24 See, for example, Christys, Vikings in the South. 


\section{References}

\section{Abbreviations}

Halper 317 = Philadelphia, University of Pennsylvania, Center for Advanced Judaic Studies Library, Cairo Genizah Collection, Halper 317.

Aenigmata in Dei nomine Tullii seu aenigmata quaestionum artis rhetoricae [aenigmata sbernensia ], ed. Fr. Glorie, trans. Karl J. Minst, in: Tatuini omnia opera, Variae collectiones aenigmatum merovingicae aetatis, Anonymus de dubiis nominibus, Fr. Glorie (ed.), Corpus christianorum: series latina 133-133a, 2 vols (Turnholt, 1968) II 541-610.

Al-Ḥarizi, Yehudah ben Shelomo, תחכמוני, taḥkemoni, ed. Paulus Lagarde, Iudae Harizii macamae (Göttingen, 1883); trans. Victor Emanuel Reichert, The Tahkemoni of Judah al-Harizi, 2 vols (Jerusalem, 1965-1973).

Björn Jónsson á Skarðsá, Uttlegging Bjarna Jónssonar uppábessargátur Gestsins blinda, almenningi, til frekari skilnings, ed. Philip Lavender, Oedipus industrius ænigmatum islandicorum: Björn Jónsson á Skarðsá’s Riddle Commentary, Gripla 26 (2015) 229-273.

Burrows, Hannah, Enigma variations: wave-riddles and supernatural women in Old Norse poetic tradition, Journal of English and Germanic Philology 112 (2013) 194-216.

Burrows, Hannah, Wit and wisdom: the worldview of the Old Norse-Icelandic riddles and their relationship to Eddic poetry, in: Martin Chase (ed.), Eddic, Skaldic, and Beyond: Poetic Variety in Medieval Iceland and Norway (New York, 2014) 114-135.

Christys, Ann, Vikings in the South (London, 2015)

Delgado, José Martínez, Dunash ben Labrat ha-Levi, in: Norman A. Stillman et al. (eds.), Encyclopedia of Jews in the Islamic World (Leiden, 2010).

Dictionary of Old Norse Prose (Copenhagen, 1983-).

Dunash ben Labrat ha-Levi, דיוואן, diwan [diwan], trans. Carlos del Valle Rodríguez, El diván poético de Dunash ben Labraț: la introducción de la métrica árabe (Madrid, 1988).

Dunash ben Labrat ha-Levi, חידות, hidot [riddles], ed. Nehemya Aluny, Ten Dunash ben Labrat's riddles, The Jewish Quarterly Review, New Series 36 (1945) 141-146.

The Exeter Book, ed. George Philip Krapp and Elliott Van Kirk Dobbie, The Anglo-Saxon Poetic Records 3 (New York: Columbia University Press, 1936).

Gátur, ed. Hannah Burrows, in: Kari Ellen Gade and Edith Marold (eds.), Poetry from Treatises on Poetics: Part 1, Skaldic Poetry of the Scandinavian Middle Ages 3 (Turnhout, 2017) 631-636.

Hall, Alaric, Changing style and changing meaning: Icelandic historiography and the medieval redactions of Heiðreks saga, Scandinavian Studies 77 (2005) 1-30.

Hall, Alaric and Shamira A. Meghani, »I am a virgin woman and a virgin woman's child«: Critical plant theory and the maiden mother conceit in early medieval riddles, Medieval Worlds 14 (2021) 265-288.

Hervarar saga ok Heiðreks, ed. and trans. Hannah Burrows, in: Margaret Clunies Ross (ed.), Poetry in >Fornaldarsögurı: Part 1, Skaldic Poetry of the Scandinavian Middle Ages 8 (Turnhout, 2017) 367-487. 
Ibn Gabirol, Shelomo ben Yehudah, שירי שלמה בן יהודה אבן גבירול :מקובצים על פי ספרים וכתבי־, Shire Shelomoh ben Yehudah ibn Gabirol: mekubatsim ' al-pi sefarim ye-kitve-yad [poems of Shelomoh ben Yehudah ibn Gabirol: compiled from books and manuscripts], ed. Hayyim Nahman Bialik and Yehoshua Hana Rawnitzki, 7 vols (Tel 'Aviv, 1927-1932).

Klein, Thomas, Pater occultus: the Latin Bern Riddles and their place in early medieval riddling, Neophilologus 103 (2019) 399-417.

Lavender, Philip, Djalar-Jóns saga, Leeds Studies in English, n.s. 46 (2015) 73-113.

Lewis, Charlton T. and Charles Short, A Latin Dictionary, Founded on Andrews' Edition of Freund's Latin Dictionary, Revised, Enlarged, and in Great Part Rewritten (Oxford, 1879).

Markey, Tom, >Garlic and Sapphires in the Mud«: ১Leeks in their Early Folk Contexts, Leeds Studies in English, n. s. 44 (2013) 10-42.

Mogford, Neville, The moon and stars in the Bern and Eusebius riddles, in: Megan Cavell and Jennifer Neville (eds.), Riddles at Work in the Early Medieval Tradition: Words, Ideas, Interactions (Manchester, 2020) 230-246.

Oxford English Dictionary Online, (3rd edition), (Oxford, 2013) s.v. head, n. 1.

Pagis, Dan, Toward a theory of the literary riddle, in: Galit Hasan-Rokem and David Shulman (eds.), Untying the Knot: On Riddles and Other Enigmatic Modes (Oxford, 1996) 81-108.

Philadelphia, University of Pennsylvania, Center for Advanced Judaic Studies Library, Cairo Genizah Collection, Halper 317; open-access facsimile: http://openn.library.upenn.edu/ Data/0002/html/h317.html.

The Saga of King Heidrek the Wise, ed. and trans. Christopher Tolkien (London, 1960).

Stefán Karlsson, Aldur Hauksbókar, Fróðskaparrit 13 (1964) 114-121.

Vijūna, Aurelijus, On the Old Icelandic riddle collection Heiðreksgátur, Scandinavistica Vilnensis 9 (2014) 167-180. 